Iranian Quarterly Journal of Breast Disease. 2020; 12(4):8.
Original Article

\section{Assessing Self-efficacy for Coping with Cancer: Psychometric Analysis of the Cancer Behavior Inventory (CBI)}

\author{
Karamoozian $\mathbf{M}^{1}$, Kalantari Khandani $\mathbf{B}^{2}$, Bagheri $\mathbf{M}^{3^{*}}$, Dehghanifar $\mathbf{F}^{4}$, \\ Darekordi A \\ ${ }^{1}$ Neuroscience Research Center, Institute of Neuropharmacology, Kerman University of Medical \\ Sciences, Kerman, Iran \\ ${ }^{2}$ Dept of Oncology, Faculty of Medicine, Kerman University of Medical Sciences, Kerman, Iran \\ ${ }^{3}$ Dept of Psychology, University of Shahid Bahonar Kerman, Kerman, Iran \\ ${ }^{4}$ Ph.D. Student in Psychology, Dept of Psychology, Islamic Azad university of Zarand, Kerman, \\ Iran \\ ${ }^{5}$ Dept of Psychology Payame Noor University of Kerman, Kerman, Iran
}

Receive: $26 / 2 / 2019$

Accepted: 14/12/2019

*Corresponding Author: mbagheri@uk.ac.ir

Ethics Approval: IR.E.A. 97.12.11.01

\begin{abstract}
Introduction: Self-efficacy refers to an individual's belief in their capacity to execute a specific behavior. Believing that individuals themselves are responsible for their health can lead to the adoption of health behaviors. This study aimed to conduct a confirmatory factor analysis of a Cancer Behavior Inventory (CBI) for Iranian female breast cancer patients.
\end{abstract}

Methods: This was a descriptive-analytic study. First, we establishing the content and face validity of the instrument. Then, 345 breast cancer patients were selected from cancer treatment centers of Kerman city by convenience sampling to evaluate the psychometric properties of the instrument. The participants completed the CBI and the General Self-efficacy Scale. The instrument validity was assessed using exploratory and confirmatory factor analysis (structural validity) and correlational methods (concurrent validity), and the internal and external reliability were evaluated by calculating Cronbach's alpha coefficients and using the test-retest method, respectively. Analyses were performed using SPSS 19 and AMOS software packages.

Results: Confirmatory factor analysis of the 31-item questionnaire, consisting of 7 subscales, was conducted after removing items 3 and 5. A significant correlation between each subscale and the General Self-efficacy Scale and also between the overall scale and the General Self-efficacy Scale confirmed the concurrent validity of the questionnaire. The reliability of the questionnaire was confirmed based on a Cronbach's alpha coefficient value of 0.75 (ranging from 0.69 to 0.74 for the seven factors). The 1-month test-retest reliability, assessed by readministering the test to 30 cancer patients, ranged between 0.67 and $0.74(\mathrm{P}<0.01)$, which shows acceptable reliability of the $\mathrm{CBI}$ over time.

Conclusion: The CBI has acceptable validity and reliability. The seven factors extracted for the CBI matched those identified in the original version. The present study introduces a tool that can be useful in assessing and evaluating the self-efficacy of breast cancer patients during treatment.

Keywords: Self-Efficacy, Cancer, Psychometrics, Cancer Behavior Inventory 
مقاله بڤروهشى

ارزيابى خودكار آمدى براى مقابله با سرطان: تحليل روانسنجى

ير بشنامه رفتار هاى مربوط به سرطان (CBI)

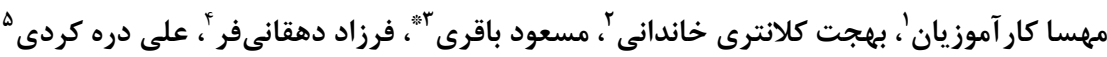
' مركز تحقيقات علوم اعصاب، يزوهشكده نوروفارماكولوزى، دانشكاه علوم يزشكى كرمان، كران، كرمان، ايران

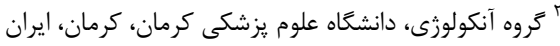

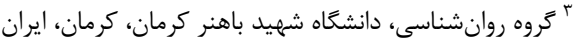

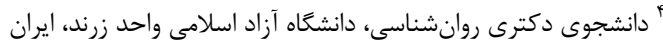

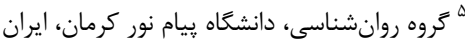

فصلنامه بيمارى هاى يستان ايران

$\operatorname{Irq\Lambda } \operatorname{Ir}(\varepsilon): \Lambda-r$.

\section{0 our?}

مقدمه: خودكارآمدى به باور فردى در خصوص انجام رفتار تاكيد مى كند و باور به اين نكته كه تا

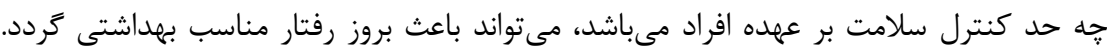

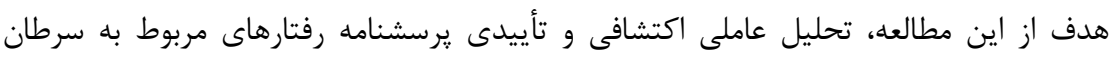

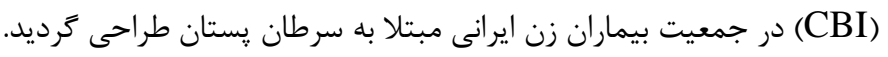

روش بررسى: مطالعه حاضر يك مطالعه توصيفى- تحليلى است. يس از تأييد روايى صورى و

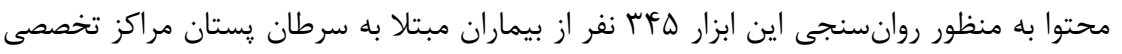

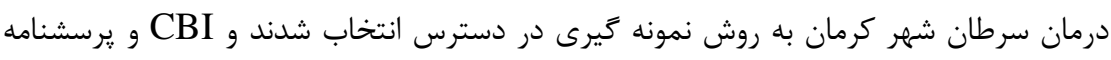

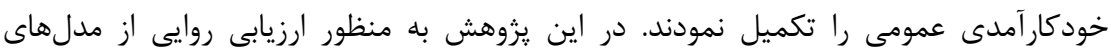

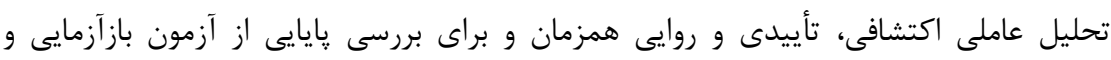
ضرايب آزمون آلفاى كرونباخ در نرم افزار

يافتهها: تحليل عاملى تأييدى يرسشنامه اب آيتمى با V خرده مقياس آن، با حذف عبارت ب و هـ

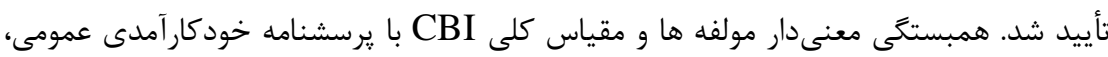

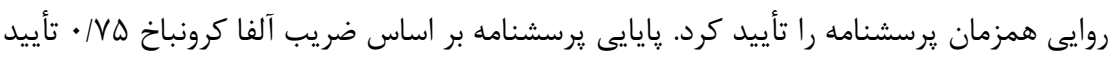

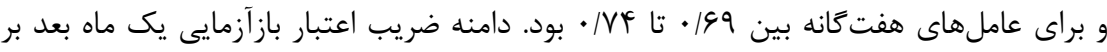

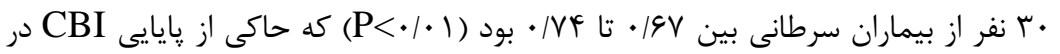

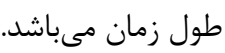

نتيجهَيرى: CBI ويزگى هاى روانسنجى لازم را دارد. در اين يزوهش هفت عامل استخراج

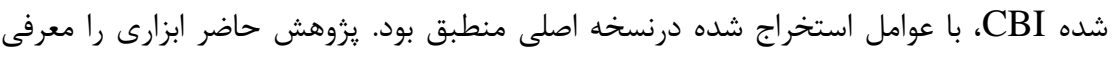

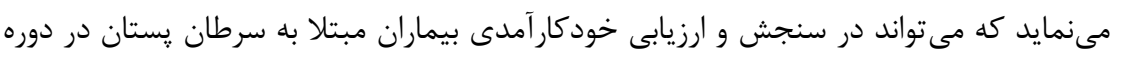
درمان سودمند واقع شود.

وازههاى كليدى: خودكارآمدى، سرطان، روانسنجى، پرسشنامه رفتارهاى مربوط به سرطان

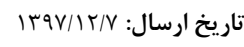
تاريخ يذيرش: rاريخ ارسال:

"ن mbagheri@uk.ac.ir 
مقياس خودكارآمدى احساسى استنفورد (1/ (SSES-21)

يرسشنامه سازكارى روانى با سرطان (SICPA)، يك ابزار

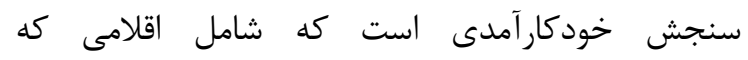

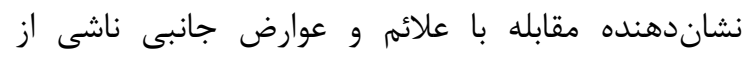

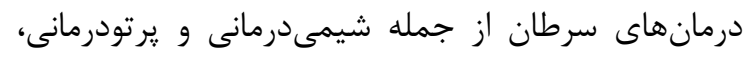

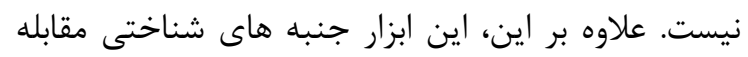

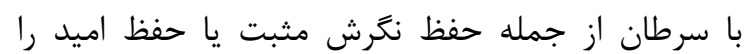

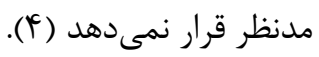

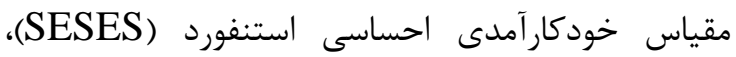

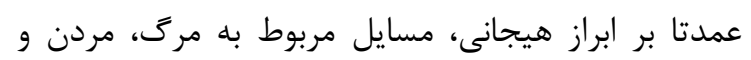

متمركز بر زمان حاضر است (1) (1).

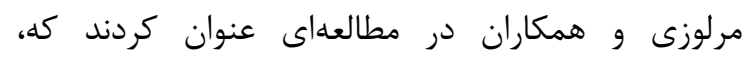

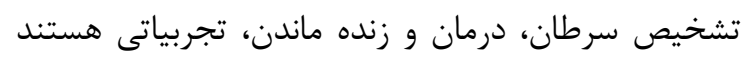

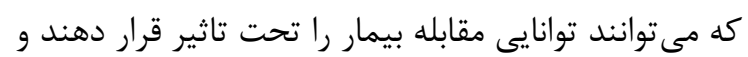

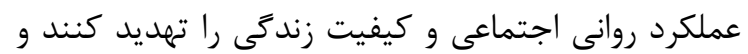

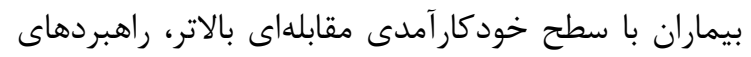

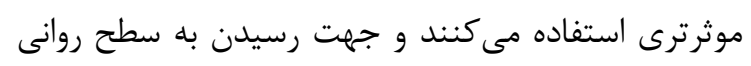

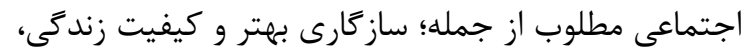
و نتايج يزشكى از جمله كاهش شدت علايم و عوارض جانبى، پايدارى بيشترى نشان مى دهند.

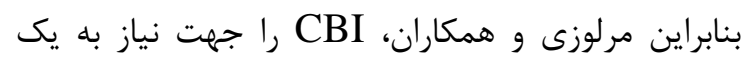

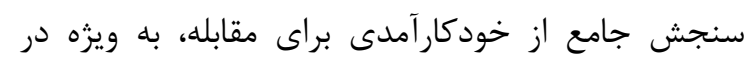

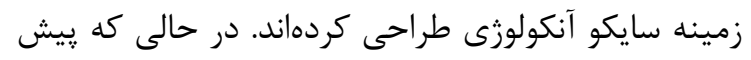

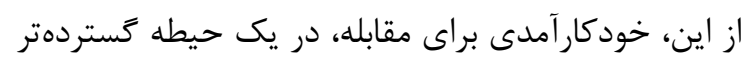

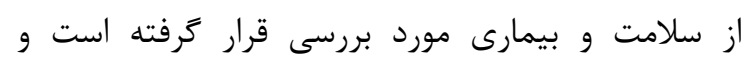

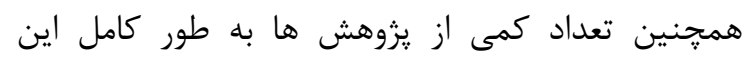
ساختار را با توجه به سرطان بررسى كردهان انداند. اين ابزار

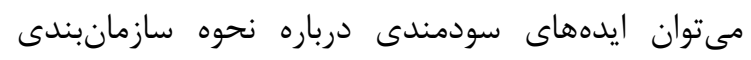

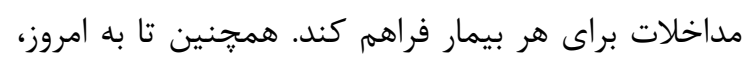

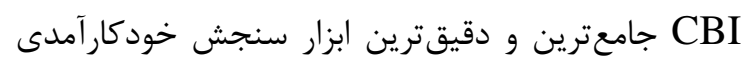

جهت مقابله با سرطان است (؟). بنابراين با توجه به اهميت ميزان خودكارآمدى در مر مقابله

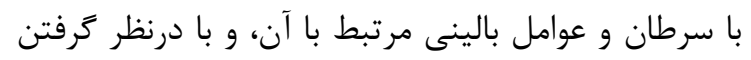

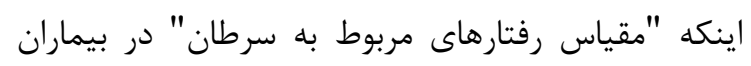
مبتلا به سرطان، روان سنجى نشده و تاكنون ابزارى روا و

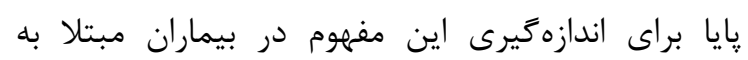

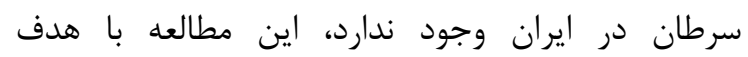
روانسنجى نسخه فارسى "مقياس رفتارهاى مربوط به به بـ

\section{مقدمه}

نظريه خودكارآمدى سابقه طولانى در ارزيابى و هدايت

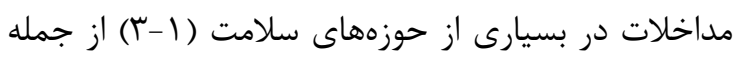

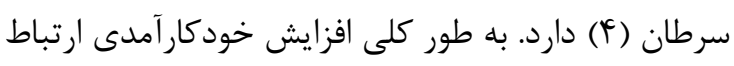

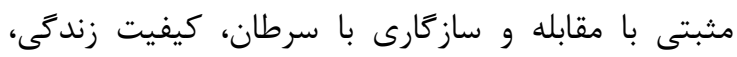
خلق مثبت و جستجوى درمان (أ، ه) و همجنين ارتباط منفى با علايم سرطان (ع، V) دارد.

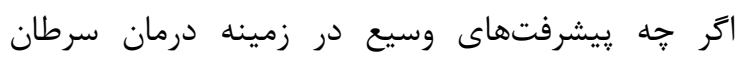
موجب واكنش بهتر تومور به درمانها و افزايش طول عمر دران

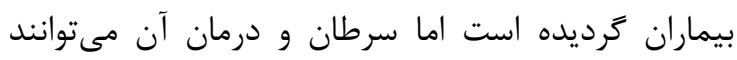

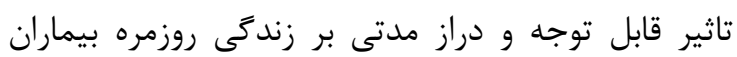

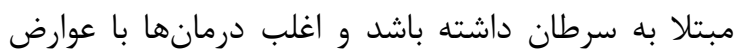

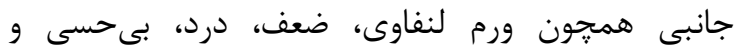

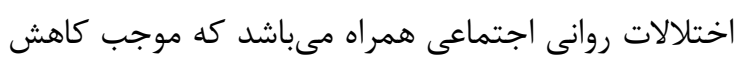

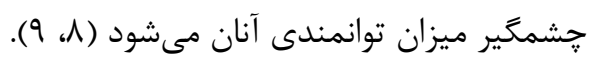

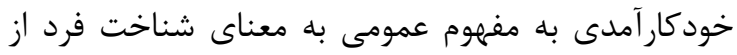

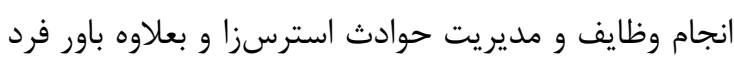

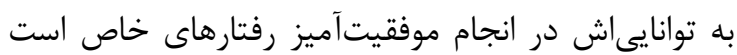

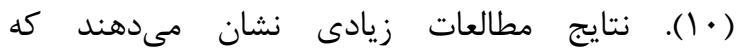

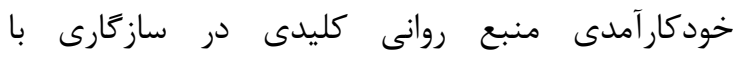

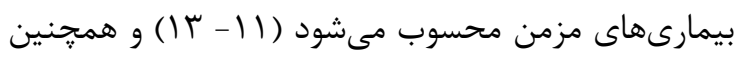

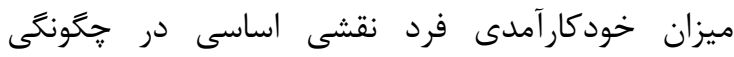

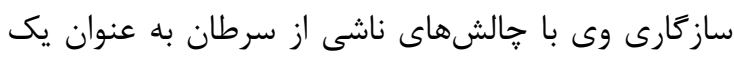

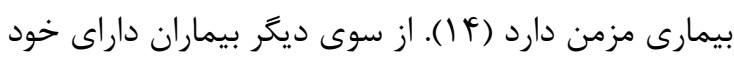

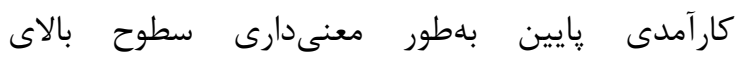

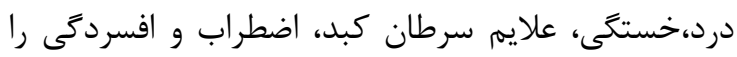

تجربه مى كنند (9). در اين راستا تشويق بيماران براى اتخاذ رويكردى فعال

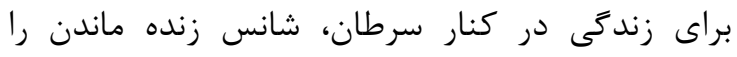

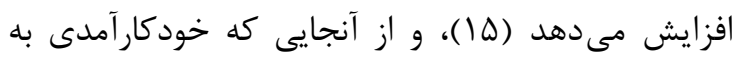

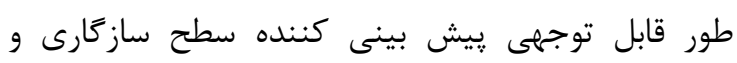

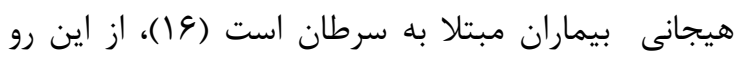
سنجش ميزان خودكارآمدى در برخورد با بيمارى هائ هاى

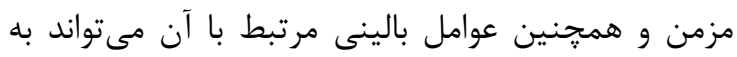

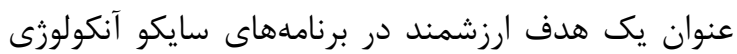

$$
\text { مورد توجه قرار گيرد. }
$$

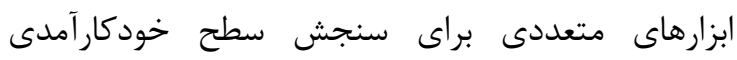

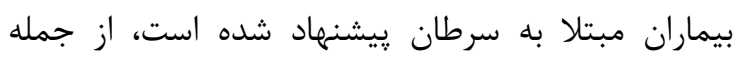

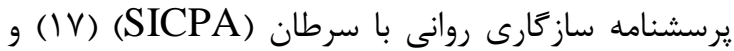




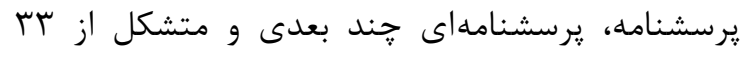
ماده است كه هفت خرده مقياس دارد. اين خرده مقياسها عبارتند از : ادامه فعاليتها و حفظ استقلال

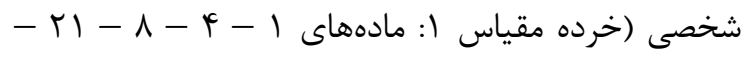

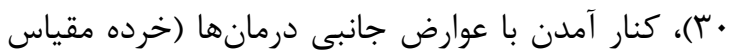
r: مادهاى •1 -

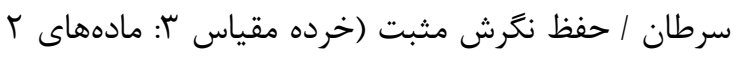

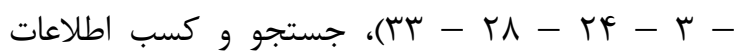
يزشكى (خرده مقياس fا: مادهاى ه - 9 - 10 - 19 - 19 -

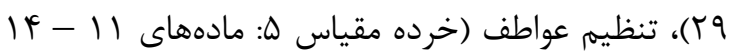

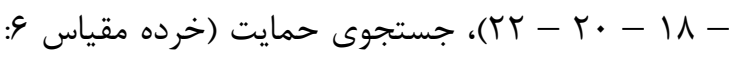

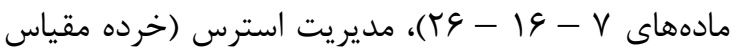
V: مادهاى 9 مقياس در يك طيف ليكرتى 9 رتبهاى (اصلاً مطمئن

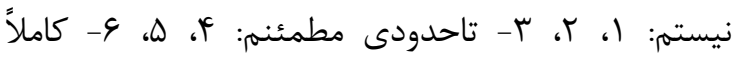

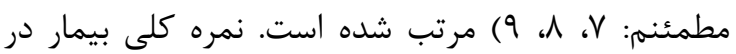
CBI

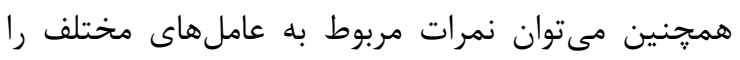

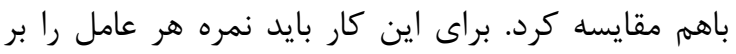

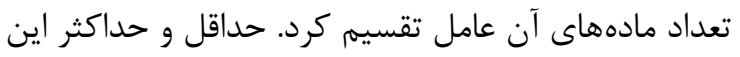

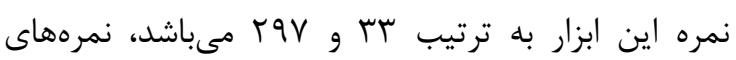

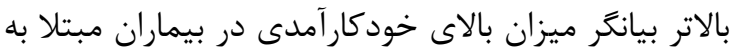

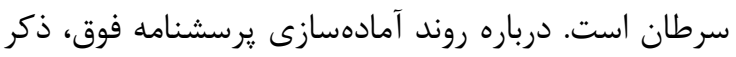

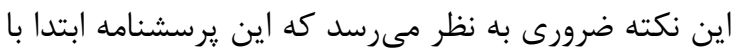

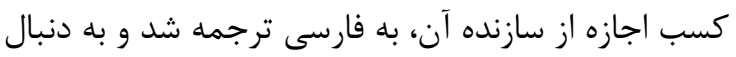

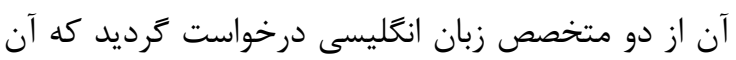

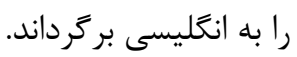

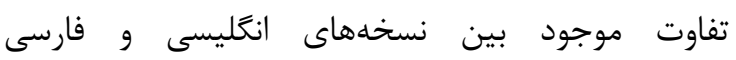

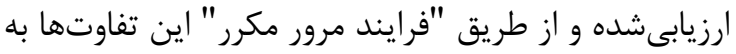
حداقل ممكن كاهش يافت. بر اين اساس، مترادف معنايى

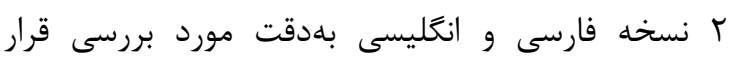

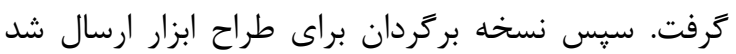

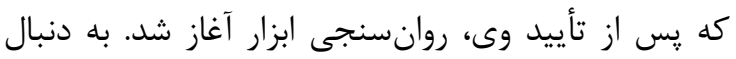

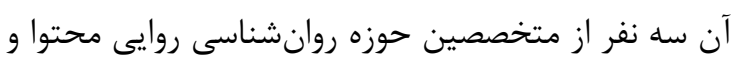
روايى صورى CBI را تأييد كردند.

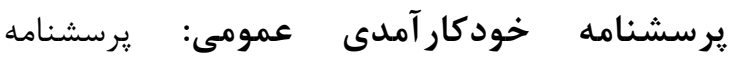

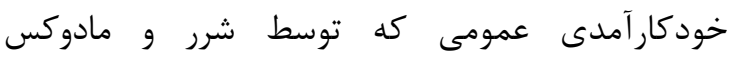

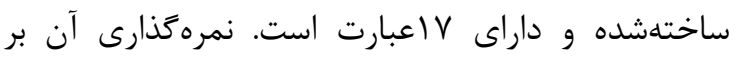
اساس طيف ليكرت است .به اين ترتيب كه به كزينههاى
سرطان" در بيماران مبتلا به سرطان يستان ايران انجام شده است.

\section{مواد و روشها}

مطالعه حاضر مطالعه توصيفى و كاربردى از نورس روانسنجى و اعتباريابى بوده است. جامعه يزوهش شامل

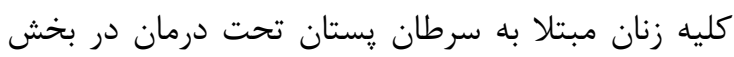

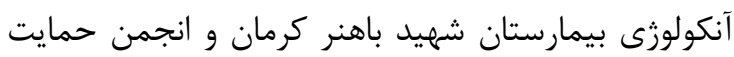
از بيماران سرطانى ياس شهركرمان مىباشد. جهت نمونه گيرى از روش نمونه گيرى در دسترس با توجيه

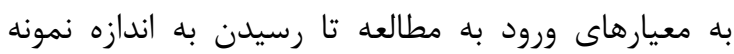

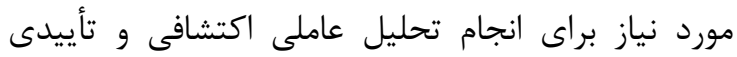
استفاده شد. بيمارانى وارد مطالعه شدند كه تشخيص

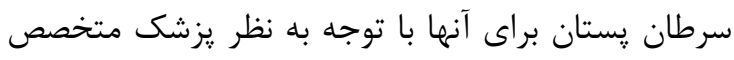

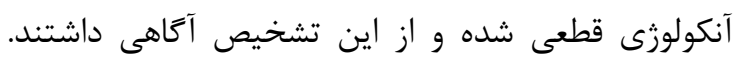
عدم وجود سابقه بيمارى عصبى و روانشناختى شديد،

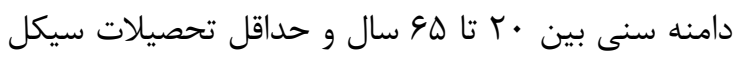

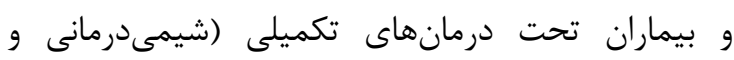

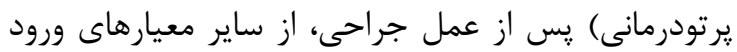

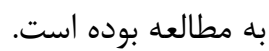

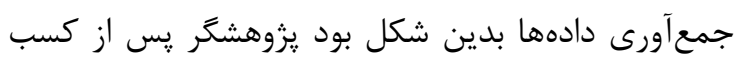

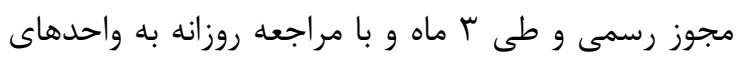

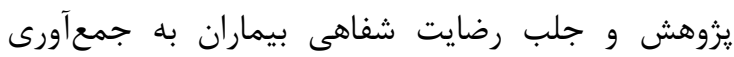

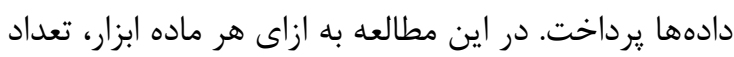

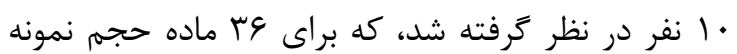

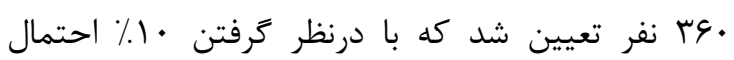

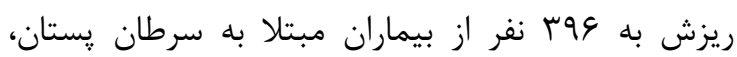

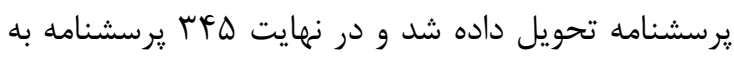
طور كامل توسط بيماران تكميل كرديد.

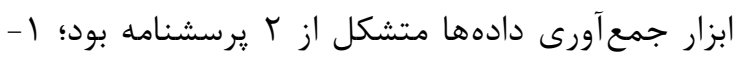

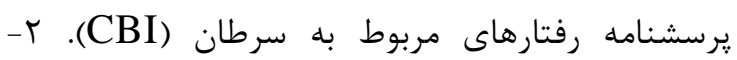

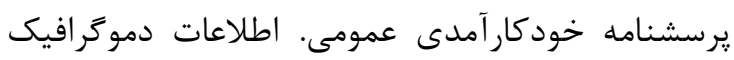

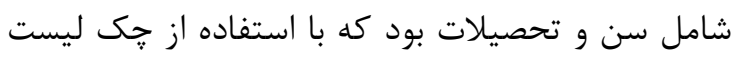
جمع آورى شد.

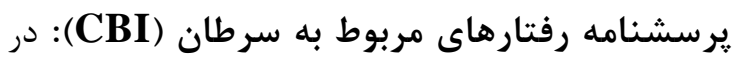
اين مطالعه جهت ارزيابى ميزان خودكارآمدى بيماران

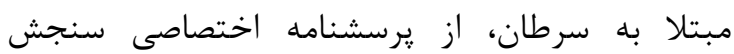

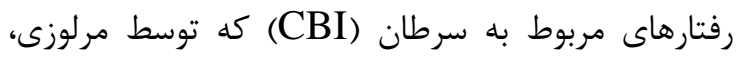

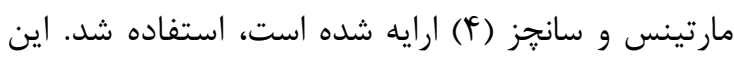




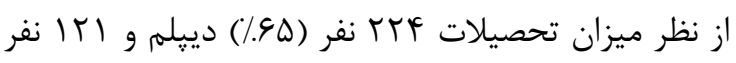

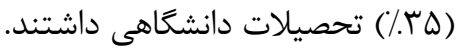

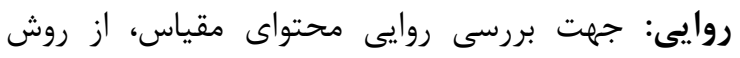

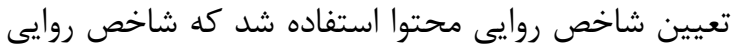
محتوا مقياس در هريك از حيطههاى مربوط بودن، واضح

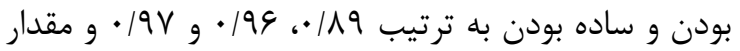
19 SCVI بلمنظور بررسى روايى سازه مقياس از تحليل عامل اكتشافى و تأييدى استفاده شد. براى بررسى كفايت نمونهيرى و معنادارى ماتريس همبستگى شاخصهاى (Kaiser Meyer Olkin) KMO بررسى شد كه به (Bartlett's Test of Sphericity)

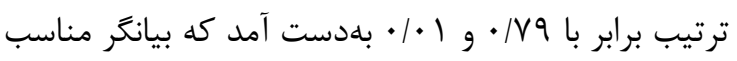
بودن روش تحليل عاملى به منظور بررسى ساختار عاملى بلى

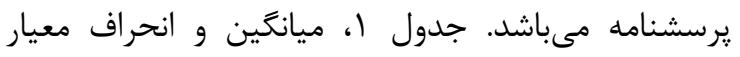

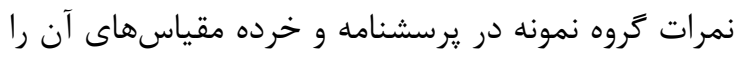
نشان مىدهد. در جدول r مقدار واريانس كل براى هر بعد

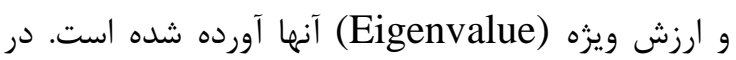

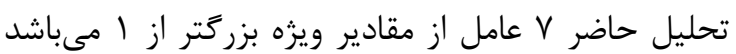

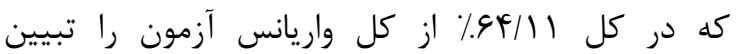

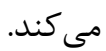

\begin{tabular}{|c|c|c|}
\hline \multicolumn{3}{|c|}{ رفتارهاى مربوط به سرطان } \\
\hline انحراف معيار & ميانگين & عاملها \\
\hline$f / \cdot F$ & $I T / V F$ & استقلال شخصى \\
\hline$f / 1 Q$ & $\mid f / \Delta \Delta$ & كنار آمدن \\
\hline$F / \& V$ & $18 / 19$ & يذيرش سرطان \\
\hline$r / v \wedge$ & $I M / M F$ & جستجو و كسب \\
\hline R/Tt & $11 / \cdot V$ & تنظيم عواطف \\
\hline$F / 09$ & $\mid r / T \Lambda$ & جستجوى حمايت \\
\hline$r / \cdot \Delta$ & १/AV & مديريت استرس \\
\hline$\Lambda / 9 \Lambda$ & $\Lambda \Lambda / \cdot V$ & مقياس كلى \\
\hline
\end{tabular}

براى كشف ساختار عاملى CBI در نمونه يزوهش از تحليل مؤلفههاى اصلى با استفاده از ترخش واريماكس

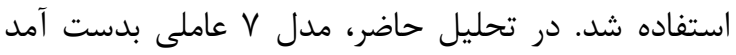

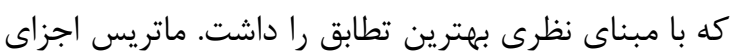
جرخش يافته در جدول شماره ؟ نشان داده شده است.
كاملاً موافقم، موافقم، نه موافق و نه مخالف، مخالفم و

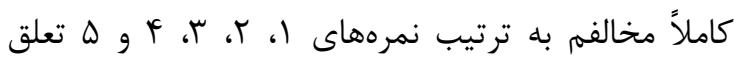

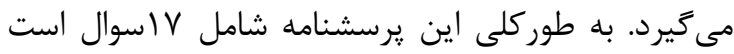

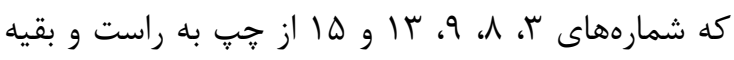

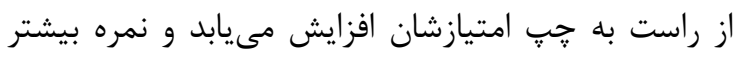

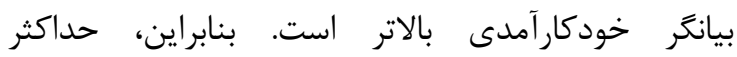

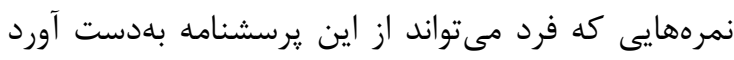

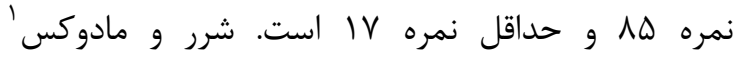

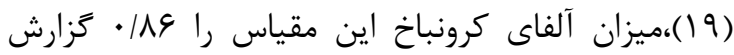

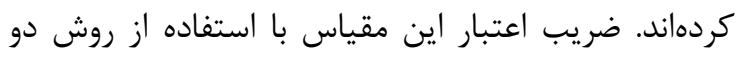

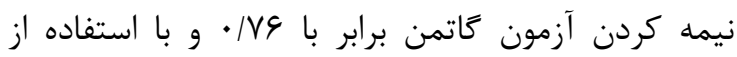

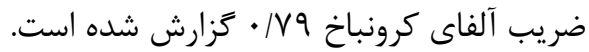
اين مطالعه با كسب مجوز از مراكز درمانى آنكولوزى شهر

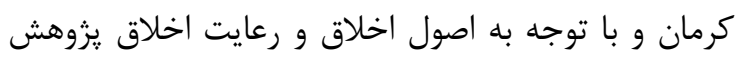
انجام شد. كليه شركت كنندكان نيز آكاهانه در مطالعه شركت كردند و به آنها اطمينان داده شد كه اطنلاعات

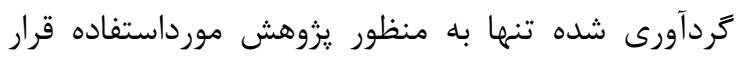

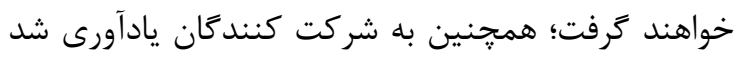
كه در هر زمانى قادر به خروج از روند يزوهش هستند.

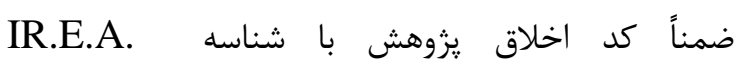
97.12.11.01 توسط كميته اخلاق دانشعاه شهيد باهنر كرمان رعايت شده است.

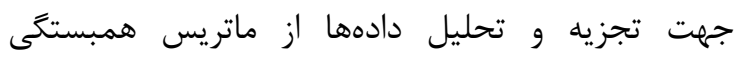

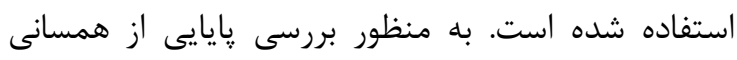

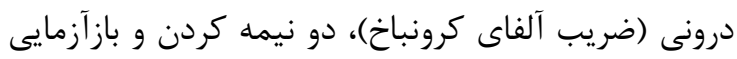

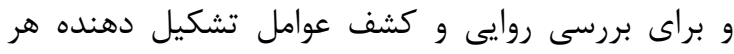

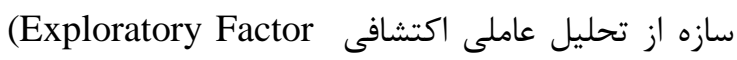
(Confirmatory Factor و سيس تأييدى (Analysis) Analysis)

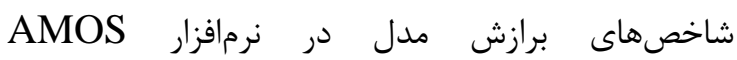
SPSS در (Analysis of moment structure)

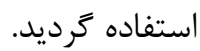

يافتهها در مجموع دادهاى مربوط به سFD نفر از افراد مبتلا به

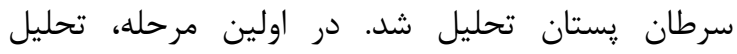

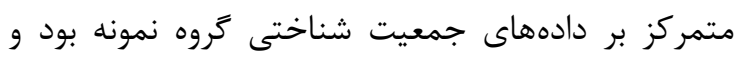

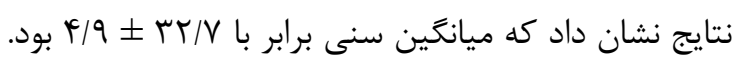

\footnotetext{
${ }^{1}$ Sherer \& Maddox
} 
جدول r: مشخصههاى آمارى اوليه در اجراى تحليل مولفههاى اصلى

\begin{tabular}{|c|c|c|c|}
\hline \multicolumn{4}{|c|}{ عناصر تحليل عاملى } \\
\hline درصد تراكمى واريانس تبيين شده & درصد واريانس تبيين شده & مقدار ويزه & عامل ها \\
\hline$r \mid / F I r$ & $r M / F I T$ & $\mathrm{~V} / .99$ & 1 \\
\hline rI/991 & $1 \cdot / \pi V q$ & r/rqr & r \\
\hline$F \cdot / K F F$ & N/DQH & T/ATt & r \\
\hline FV/FG. & $V / T I V$ & t/rNt & r \\
\hline$\Delta T / \Delta S V$ & $9 / 1 \cdot 9$ & $r / \cdot 10$ & $\Delta$ \\
\hline$\Delta 9 / F \cdot \Delta$ & $\Delta / \wedge r \wedge$ & 1/9TV & \& \\
\hline $94 / 110$ & $F / V I$ & $1 / \Delta \Delta F$ & v \\
\hline & r/9F\& & $\cdot / 9 \wedge \Delta$ & $\wedge$ \\
\hline & $r / 9 r \wedge$ &.$/ 994$ & 9 \\
\hline & $r / 911$ & .1991 & 1. \\
\hline & $r / A \Lambda \Lambda$ & . $19 \Delta r$ & 11 \\
\hline & r/DG. & $\cdot \mid \Lambda F \Delta$ & it \\
\hline & $t / 4 \mid \Delta$ & $\cdot / \vee 9 \vee$ & ir \\
\hline & $r / T G$. & - MYS & If \\
\hline & $r / 1 \Lambda t$ & $\cdot / V T \cdot$ & 10 \\
\hline & $\mid / v 91$ & $\cdot|\Delta \Lambda|$ & 19 \\
\hline & $1 / 911$ & $\cdot / \Delta \Delta \Delta$ & IV \\
\hline & I/FTr &.$/ 4 \& 9$ & 19 \\
\hline & $1 / 19 F$ & $\cdot / r \wedge F$ & $r$. \\
\hline & $1 / .19$ & צrr/. & YI \\
\hline &.$/ 91 \pi$ & $\cdot / r \cdot 1$ & Tr \\
\hline & $\cdot / V \& D$ & - /TAY & r \\
\hline & $\cdot / 219$ & . RTV & rF \\
\hline & $\cdot 19 \wedge \Lambda$ & . ITTV & $r \Delta$ \\
\hline & . IDQT &.$/ 190$ & Tद \\
\hline & - /fAr & $\cdot / 1 \Delta 9$ & TV \\
\hline & $\cdot / r \vee \wedge$ &.$/ 1 T \Delta$ & $r \Lambda$ \\
\hline & 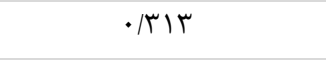 & $\cdot / 1 \cdot r$ & rq \\
\hline & $\cdot / r \cdot 1$ & .1 .99 & $r$. \\
\hline & $\cdot / r \Delta V$ & $\cdot / \cdot \wedge \Delta$ & r \\
\hline & $\cdot|r| F$ & $\cdot \mid \cdot v 1$ & rt \\
\hline & $\cdot / 11$ & $\cdot / \cdot \Delta q$ & سז \\
\hline
\end{tabular}

ز ا

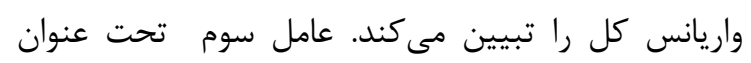
يذيرش سرطان / حفظ نكرش مثبت نام دارد كه مادهاى

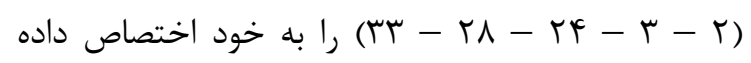

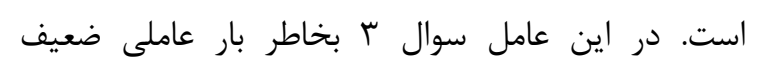

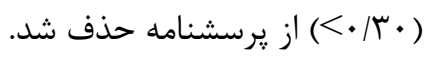

جدول r مؤلفههاى استخراج شده و همجنين گويلهاى

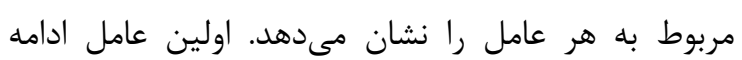

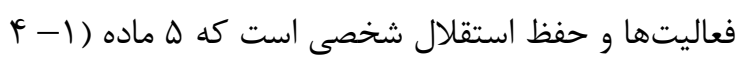

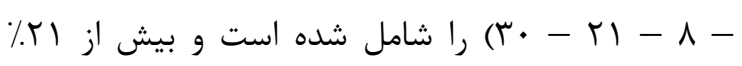
واريانس كل را به خود اختصاص داده است. عامل كنار

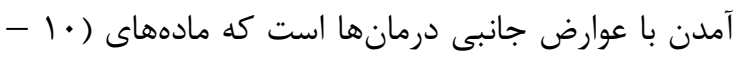


جدول ب: نتايج بارهاى عاملى CBI در تحليل اكتشافى

\begin{tabular}{|c|c|c|c|c|c|c|c|}
\hline 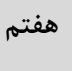 & ششم & لينجم & 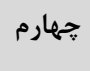 & 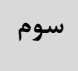 & 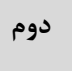 & اول & 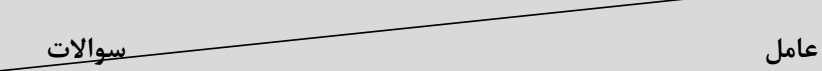 \\
\hline & & & & & & $\cdot / \pi r$ & استقلال خود را حفظ مى كنم ا \\
\hline & & & & & & $\cdot / 4 \mathrm{~V}$ & 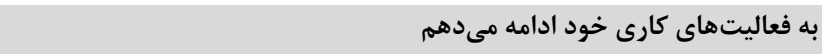 \\
\hline & & & & & & $\cdot 109$ & برنامه روزانهام را ادامه مى دهم \\
\hline & & & & & & $\cdot / \Delta V$ & خودم را با فعاليتهاى مختلف سركرم مىكنم \\
\hline & & & & & & .199 & 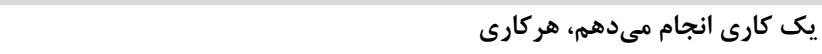 \\
\hline & & & & & $\cdot / 4 r$ & & با ريزش موهايم كنار مى آيم \\
\hline & & & & & $\cdot / 49$ & & با تغييرات جسمىام كنار مى آيم \\
\hline & & & & & $\cdot$ /AT & & محدوديت ها و تغييرات جسمى ناشى از درمان سرطان را مى يذيرم \\
\hline & & & & & $\cdot / \Delta \Delta$ & & دردم را كنترل مى كنه \\
\hline & & & & & $\cdot / N T$ & & حالت تهوع و استفراغم را كنترل مى كنم \\
\hline & & & & $\cdot 191$ & & & نغرش مثبتى را در بيش مى \\
\hline & & & & $\cdot / 10$ & & & مى يذيرم كه سرطان دارم" \\
\hline & & & & .199 & & & يك حس شوخ طبعى در بيش مى \\
\hline & & & & $\cdot / 49$ & & & 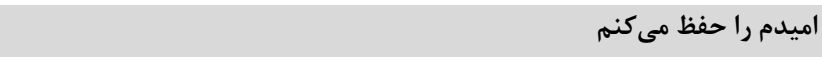 \\
\hline & & & & $\cdot / 4 \lambda$ & & & احساسهاى منفى خود را در مورد سرطان كنترل مى كنه \\
\hline & & & $\cdot / 4$ & & & & از برستاران سوالهاى خود را مى برسم" \\
\hline & & & $\cdot \pi \Delta$ & & & & از تيم درمانى سوالاتى مى يرسم \\
\hline & & & $\cdot 109$ & & & & در تصميمهاى درمانى به صورت فعال شركت مى كنمم \\
\hline & & & $\cdot / \Delta V$ & & & & در مورد سرطان و درمانهاى آن اطلاعاتى به دست مى آورم \\
\hline & & & $\cdot / Q F$ & & & & از يزشكان سوالاتى مى يرسم \\
\hline & & $\cdot / 4 F$ & & & & & مشكلاتم را انكار مى كنم \\
\hline & & .101 & & & & & جيزهايى را كه نمى توانم با آنها كنار بيايم، ناديده مى \\
\hline & & $\cdot / 49$ & & & & & احساس خشم و عصبانيت خود را نشان مى دهم \\
\hline & & $\cdot / 49$ & & & & & احساسهاى منفى خود را دربارهى سرطان نشان مىدهم \\
\hline & & . & & & & & يك راه فرارى بيدا مى كنم \\
\hline & $\cdot 199$ & & & & & & در طول درمان آرام مىمانم و اجازه نمى دهم كه افكار ترسناك مرا ناراحت كند \\
\hline & $\cdot / 4 V$ & & & & & & در طول شيمى درمانى و يرتو درمانى آرام مى مانم \\
\hline & $\cdot 194$ & & & & & & در حالى كه حداقل يك ساعت منتظر يزشك بودهام، آرام مىمانم \\
\hline & $\cdot / 4 F$ & & & & & & اضطراب مربوط به آزمايش خون را كاهش مى دههم \\
\hline & $\cdot|4|$ & & & & & & حالت تهوع مربوط به شيمىدرمانى و برتودرمانى را كاهش مىدهمم \\
\hline$\cdot / 49$ & & & & & & & سعى مى كنم از كمكهاى افراد و كروههاى غير از خانوادهام استفاده كنم \\
\hline • & & & & & & & نكَرانىهايم را با ديكر ان در ميان مى كذارم \\
\hline$\cdot / 4 \Delta$ & & & & & & & خودم را دلدارى مى دهمم \\
\hline
\end{tabular}

مى كند. عامل ششم شامل مادههاى (Yاست و تحت عنوان تنظيمم عواطف شناخته مىشود. اين عامل نيز ه/ه. از واريانس كل را تبيين مى كند. عامل هفتم جستجوى حمايت است كه مادههاى (V) -

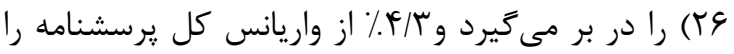

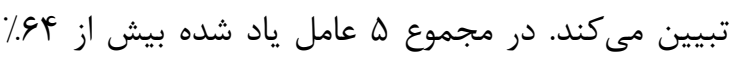
واريانس :برسشنامه را تبيين مى كنند.
اين عامل با جهار سوال ه/N/D. از واريانس كل را تبيين كرده است. عامل جهارم جستجو و كسب اطلاعات يزشكى بـ

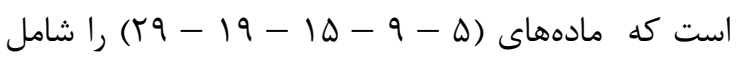
مىشود. در اين عامل نيز سوال ه بخاطر بار عاملى ضعيف

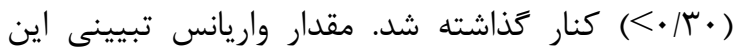

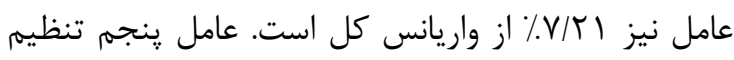
عواطف است و شامل مادهاى (1

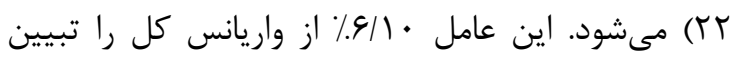


نظر معنادار هستند. در تحليل عاملى حداقل بار عاملى

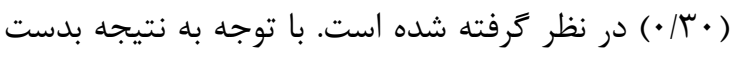
آمده از تحليل عوامل مرتبه دوم نيز؛ همبستخى يا بار عاملى هر عامل با مقياس كلى عبارتند از نظر آمارى

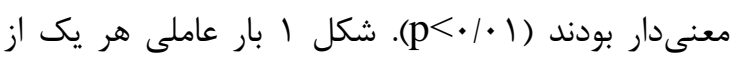
سوالات را نشان مىدهد كه نشاندهنده همبستخى هر سوال با عامل مورد نظر مىباشد.
تحليل عامل تأييدى به منظور تأييد ساختار عاملى فرض

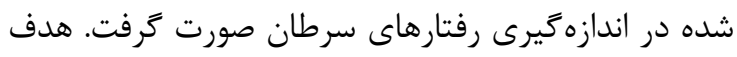
از اين اقدام، مقايسه ماتريس ساختارى اوليه با ماتريس ديس ريس ساختارى جديد بود كه از اين طريق محتواى هر عامل و همجنين ماتريس ساختارى اوليه مورد تأييد مجدد قرار

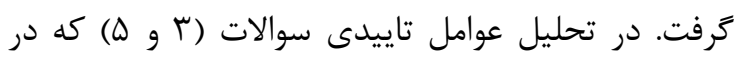
تحليل اكتشافى حذف شده بودند از تحليل خارج شدند. نتيجه بررسى نشان داد بارهاى عاملى روى عاملهاى مورد

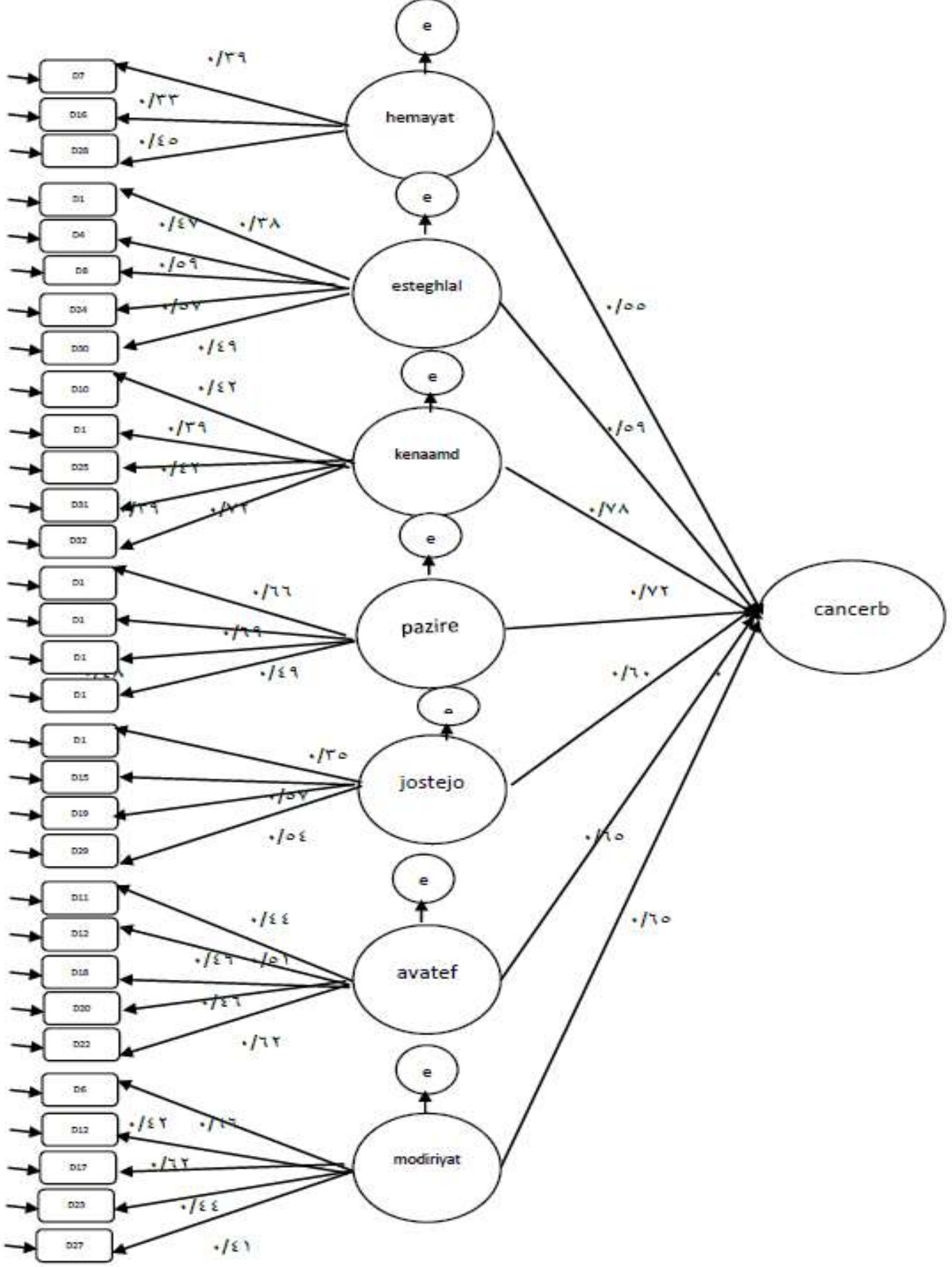

شكل ا: تحليل عامل تائيدى مرتبه اول و دوم 


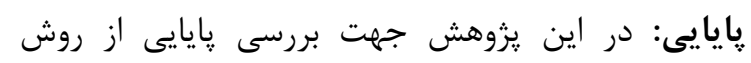

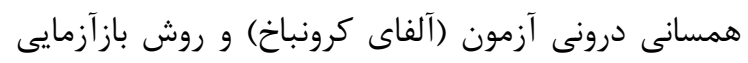

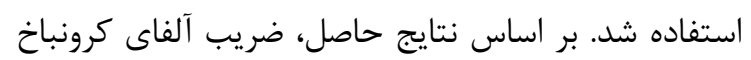

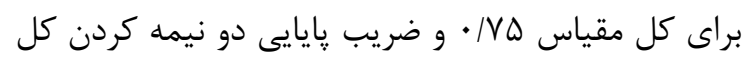

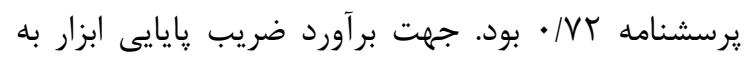

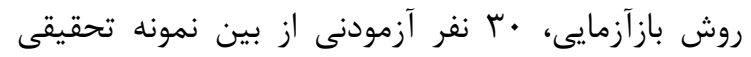

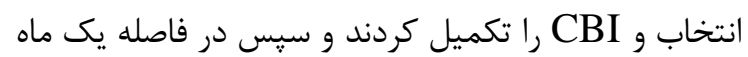

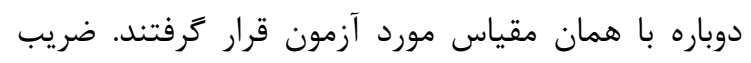

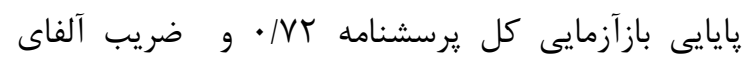

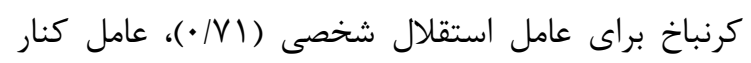

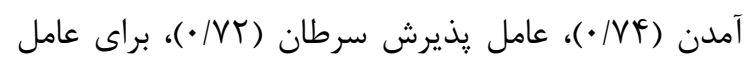

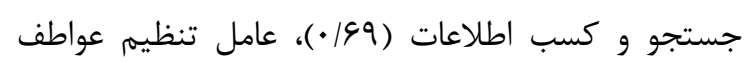

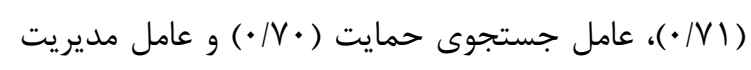

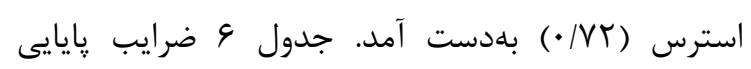

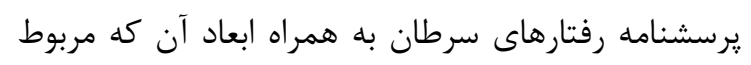

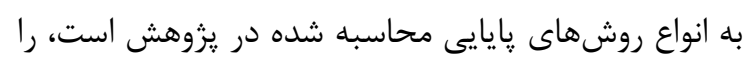

$$
\text { نشان مى دهد. }
$$

جدول f: برازش الكَوى تحليل عامل تاييدى CBI بر اساس شاخصهاى برازندكى

\begin{tabular}{|c|c|c|c|c|c|c|c|c|c|}
\hline RMSEA & $N F I$ & CFI & $A G F I$ & $T L I$ & IFI & $G F I$ & $\begin{array}{c}X^{2} / d f \\
\chi^{2} \mathbf{d f}\end{array}$ & $\chi^{2}$ & شاخص برازندكى الكَو \\
\hline .1 .9 & .191 &.$/ 9 \Delta$ &.$/ 94$ &.$/ 91$ & .190 & .199 & $F / / T$ & $V T$ & $\Lambda \cdot 1 \Delta 9$ \\
\hline
\end{tabular}

جدول ه: ضرايب همبستكى و همسانى درونى بين مقياس ها و برسشنامه اصلى

\begin{tabular}{|c|c|c|c|c|c|c|c|}
\hline مديريت & جمايت & تنظيم عواطف & جستجو و كسب اطلاعات يزشكى & سريرش & كنار آمدن با عوارض داروها & شخصى استلال & مولفه ها \\
\hline & & & & & & $* * / \Delta V$ & كنار آمدن با عوارض جانبى داروها \\
\hline & & & & & $* * \cdot / \Delta V$ & $* * \cdot 94$ & يذيرش سرطان \\
\hline & & & & $* * / 4 q$ & $* * .199$ & $* * \cdot 94$ & جستجو و كسب اطلاعات يزشكى \\
\hline & & & $* * \cdot N$ & $* * \cdot / \& V$ & $* * \cdot \mid q T$ & $* * \cdot 109$ & تنظيم عواطف \\
\hline & & $* * \cdot 194$ & $* * \cdot 1 \Delta \omega$ & $* * / \Delta T$ & $* * / \Delta V$ & $* * / V T$ & جستجوى حمايت \\
\hline & $* * \cdot 94$ & $* * \cdot 109$ & $* * \cdot \mid \Delta \varphi$ & $* * \cdot 109$ & $* * / 49$ & $* * / \Delta \Delta$ & مديريت استرس \\
\hline$* * * / \Delta \Delta$ & $* * 190$ & $* * \cdot \mid \Delta \Delta$ & $* * \cdot 199$ & $* * / V T$ & $* * / \mathrm{VA}$ & $* * \cdot 109$ & مقياس كلى \\
\hline
\end{tabular}




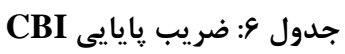

\begin{tabular}{|c|c|c|}
\hline باز آزمايى & آلفاى كرونباخ & 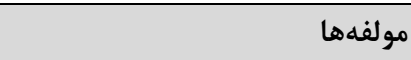 \\
\hline$\cdot / v \cdot$ & $\cdot / V \mid$ & استقلال شخصى \\
\hline$\cdot|v|$ & $\cdot / V F$ & كنار آمدن با عوارض جانبى داروها \\
\hline$\cdot / V^{k}$ & $\cdot / N T$ & يذيرش سرطان \\
\hline$\cdot / \mathrm{V}$ & .199 & جستجو و كسب اطلاعات بزشكى \\
\hline $.19 \mathrm{~V}$ & $\cdot / \mathrm{VI}$ & تنظيم عواطف \\
\hline .191 & $\cdot / V$ & جستجوى حمايت \\
\hline$\cdot|r|$ & $\cdot / V T$ & مديريت استرس \\
\hline$\cdot / V T$ & $\cdot / V \Delta$ & مقياس كلى \\
\hline
\end{tabular}

شدند. در نهايت يرسشنامه با اس عبارت و V خرده

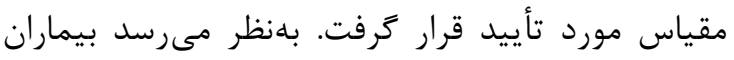

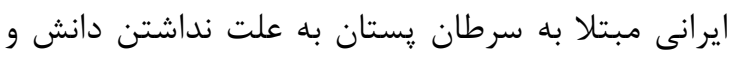

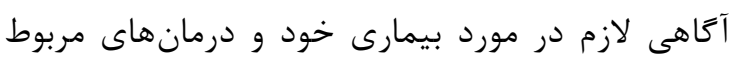

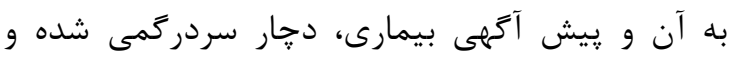

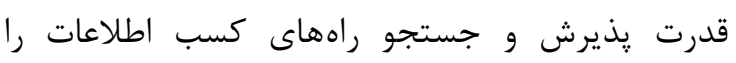
ندارند. يافته ها در بخش تحليل عاملى يرسشنامه نشان داد كه

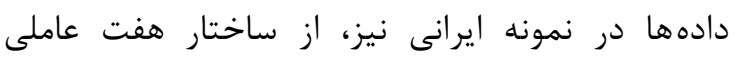

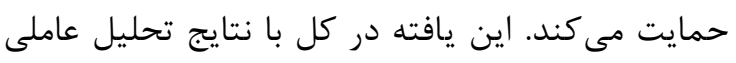

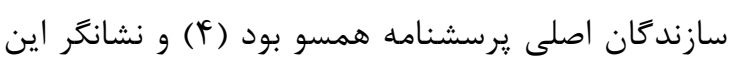

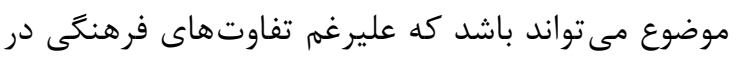

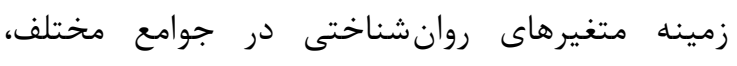

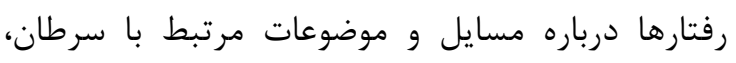

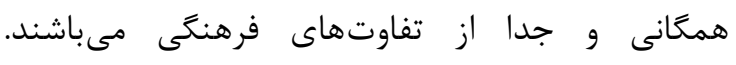

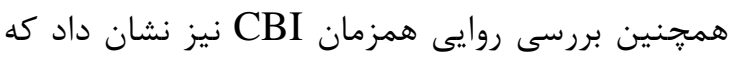

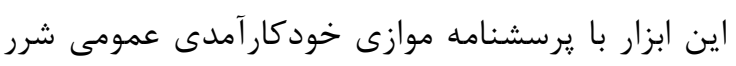

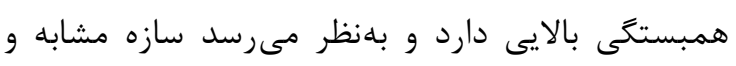

$$
\text { يكسانى را اندازه كيرى مى كنند. }
$$

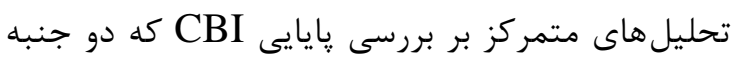

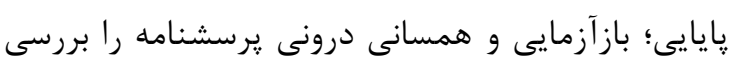

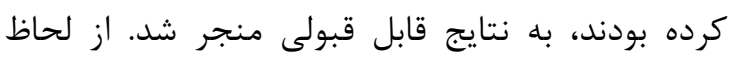

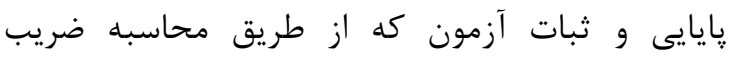

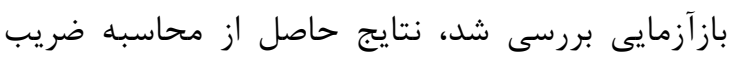

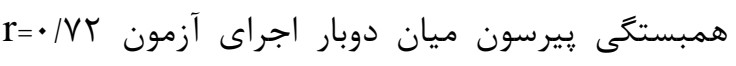

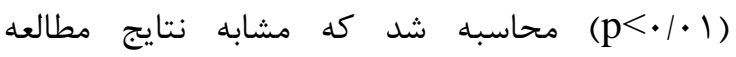

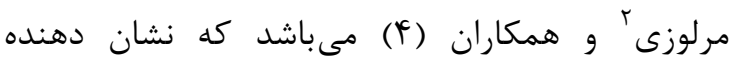
همبستكى بالا است، زيرا كه ميزان ضريب همبست (f) هيتى

\footnotetext{
${ }^{2}$ Merluzzi
}

رفتارهاى مربوط به سرطان جالش مهمى در مراقبت از

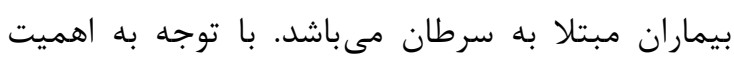

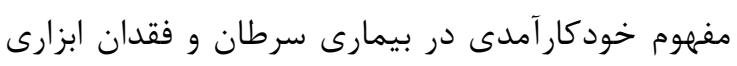

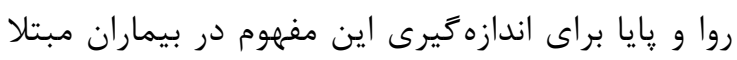

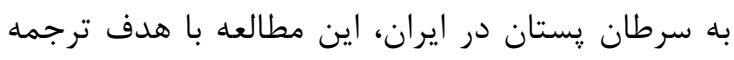
و روان سنجى نسخه ايرانى انجام كرفت.

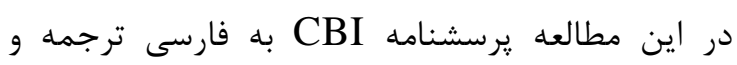

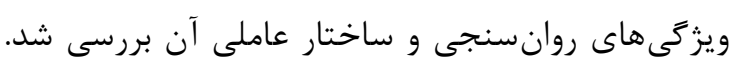

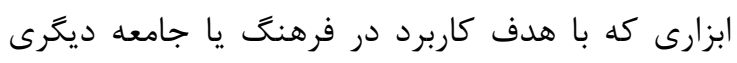

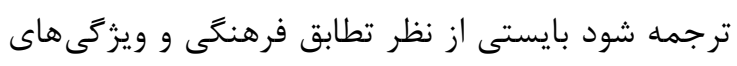

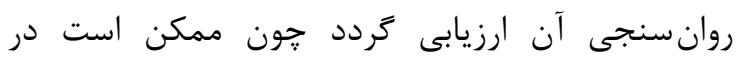
جامعه جديد مناسب نباشد (· (广).

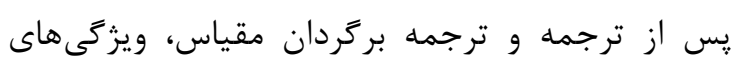

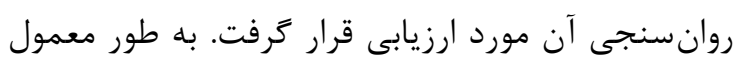

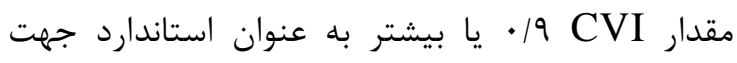

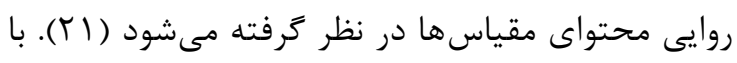

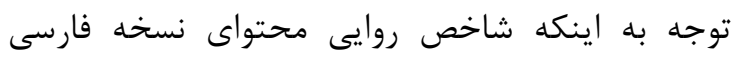

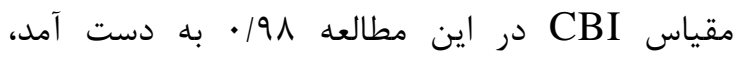
بنابراين مقياس مذكور از روايى محتواى مناسيى مطاسي

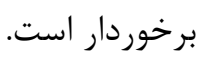
تحليل عاملى تأييدى يرسشنامه CBI با استفاده از يك لئ

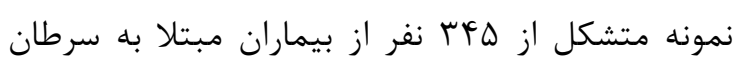

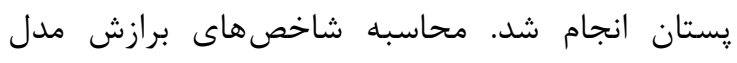

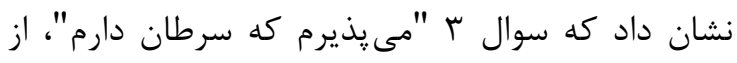

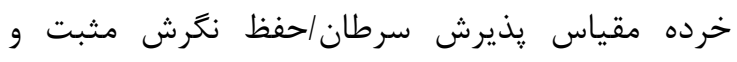

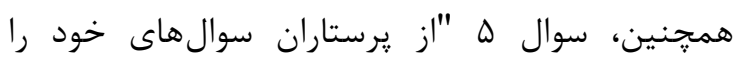

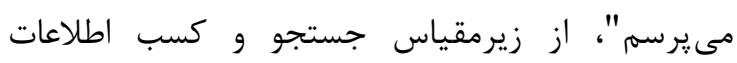

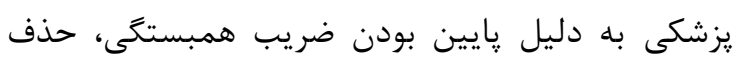


شناسايى بيمارانى كه نياز به خدمات روانشناختى دارند،

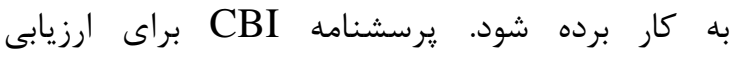

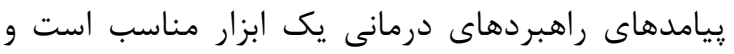

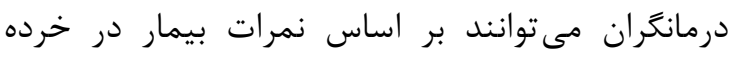

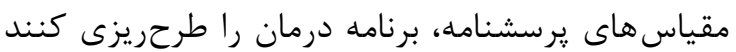

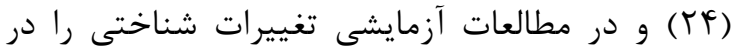

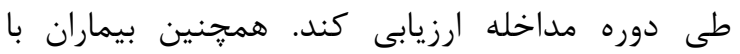
استفاده از CBI در هر نقطه از مسير بيمارى مورد ارزيابى بيى

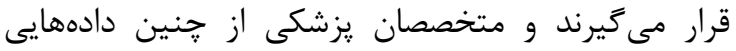
جهت سنجش خودكارآمدى براى مقابله با درمان استفاده

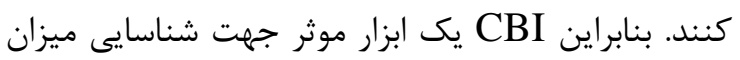

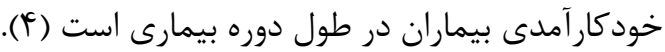
مرور شواهد تجربى در محدوده مطالعاتى خودكارآمدى دئ دياري

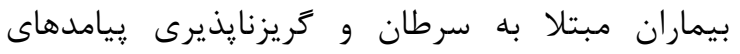
جندكانه متعاقب تشخيص سرطان، ضرورت و اهميت

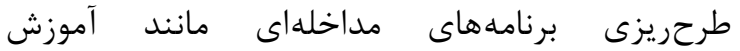

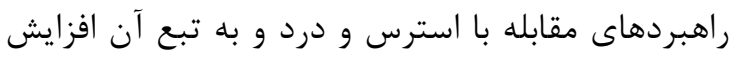

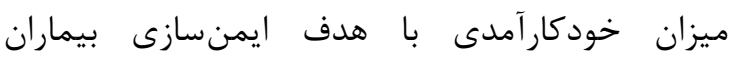
سرطانى بيش از ييش توجيه مى كند و اين امر سبب إنب إندان

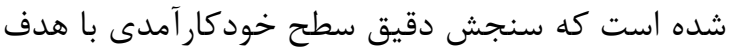

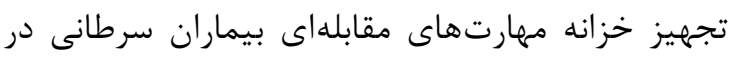
رويارويى با مطالبات غيرقابل اجتناب در كانون توجه كثيرى از محققان علاقهمند به مطالعه خودكارآمدى باري

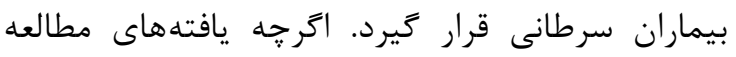
حاضر با تاكيد بر اندازههاى روانسنجى نسخه فرار فارسى CBI از بيماران سرطانى كامى ارزشمند محسوب مى شود، اما

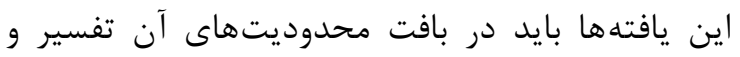

$$
\text { تعميم داده شود. }
$$

نخست، در مطالعه حاضر، از آنجا كه در تحليل

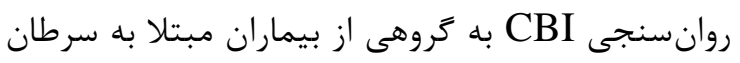

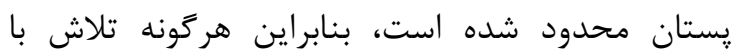
هدف بسط يا تعميم يافته ها به گروههاى ديخر مستلزم

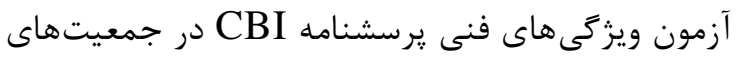

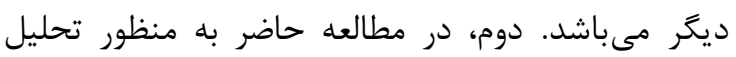
روانسنجى نسخه فارسى CBI در بيماران سرطان يستان از يك طرح مقطعى (Cross-sectional) استفاده شد.

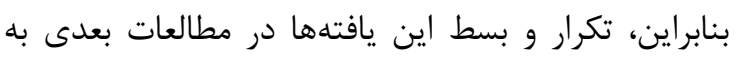

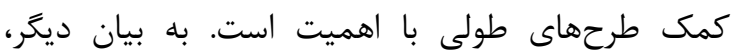

بين |+ و | أ مى باشد؛ ضريب همبستكى بين ه| • تا

1/، ، نشان دهنده همبستكى بالا است (Y) (Y).

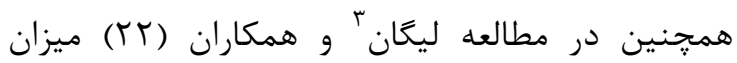

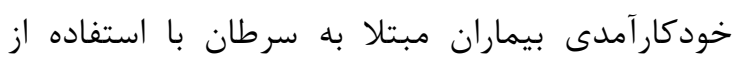
CBI قبولى براى اين برسشنامه كزارش شده است.

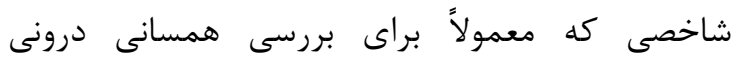
استفاده مىشود، آلفاى كرونباخ است؛ مقدار آلفاى كرونباخ حدود V/ • كافى بهنظر مىرسد و آلفاى بيشتر

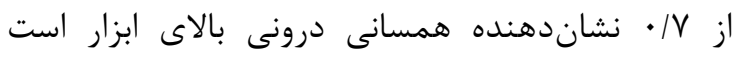

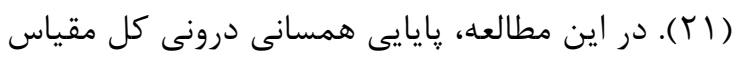

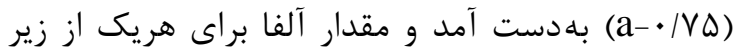

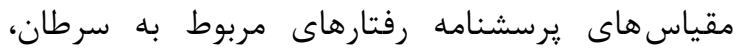

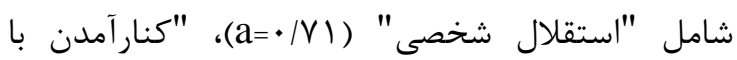

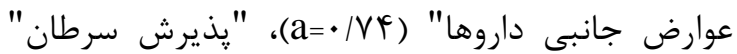
(a=/VT)

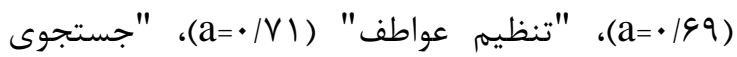
حمايت" (•) (a=/V) و "مديريت استرس" (a=/VT) محاسبه شد كه نشان مى دهد اين يرسشنامه ساختار

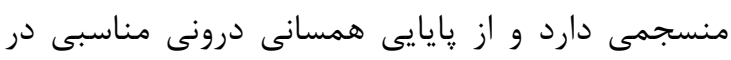

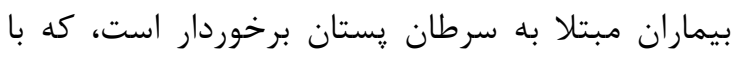

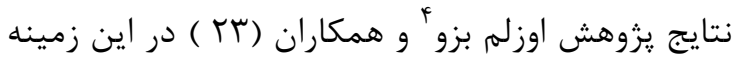

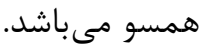
در مجموع با توجه به انجام روايى محتوا و صورى، دماند

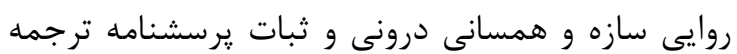
شده، مشخص گرديد كه به طور كلى نسخه فارسى

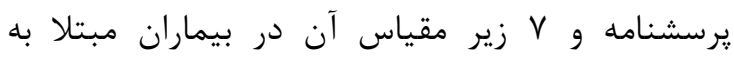

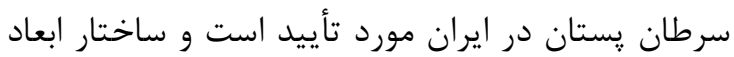

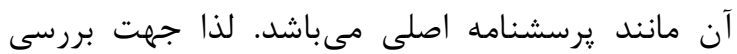

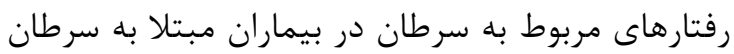
يستان در ايران قابل استفاده است.

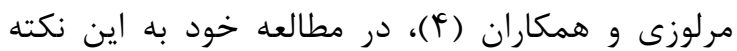

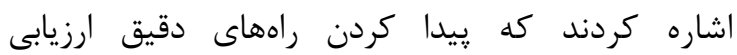
خودكارآمدى براى مقابله مىتواند نقاط قوت و و ضعف مقابله را شناسايى كند كه بايستى تقويت يا اصلاح شوند تا تا تران

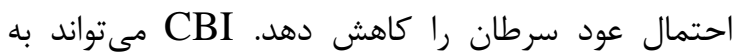
عنوان يك ابزار غربالكرى در محيطهاى بالينى جهت

${ }^{3}$ Iyigun
${ }^{4}$ Özlem Bozo 


$$
\begin{aligned}
& \text { فارسى CBI در زمينه ارزيابى و تشخيص دقيق }
\end{aligned}
$$

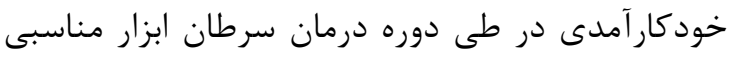

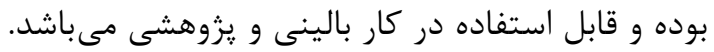

$$
\begin{aligned}
& \text { تشكر و قدردانى } \\
& \text { از تمام بيماران عزيز و همراهان آنها كه صبورانه در }
\end{aligned}
$$

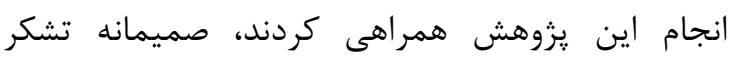

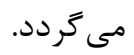

$$
\begin{aligned}
& \text { تعارض منافع } \\
& \text { نويسند } \\
& \text { يزونش حاضر وجود ندارد. }
\end{aligned}
$$

\section{References}

1. Baldwin AS, Rothman AJ, Hertel AW, Linde JA, Jeffery RW, Finch EA, et al. specifying the determinants of the initiation and maintenance of behavior change: an examination of self-efficacy, satisfaction, and smoking cessation. Health Psychol. 2006; 25(5):626-34.

2. Manning MM, Wright TL. Self-efficacy expectancies, outcome expectancies, and the persistence of pain control in childbirth. J Pers Soc Psychol. 1983; 45(2):421-31.

3. Marks R, Allegrante JP, Lorig K. A review and synthesis of research evidence for selfefficacy-enhancing interventions for reducing chronic disability: implications for health education practice (part II). Health Promot Pract. 2005; 6(2):148-56.

4. Merluzzi TV, Heitzmann CA, Jean-Pierre P, Roscoe JA, Kirsh KL, Passik SD. Assessing self-efficacy for coping with cancer: development and psychometric analysis of the brief version of the Cancer behavior inventory (CBI-B). Psychooncology. 2011; 20(3):30212.

5. Chirico A, Lucidi F, Merluzzi T, Alivernini F, Laurentiis M, Botti G, et al. A meta-analytic review of the relationship of cancer coping self-efficacy with distress and quality of life. Oncotarget. 2017; 8(22):36800-11.

6. Porter LS, Keefe FJ, Garst J, McBride CM, Baucom D. Self-efficacy for managing pain, symptoms, and function in patients with lung

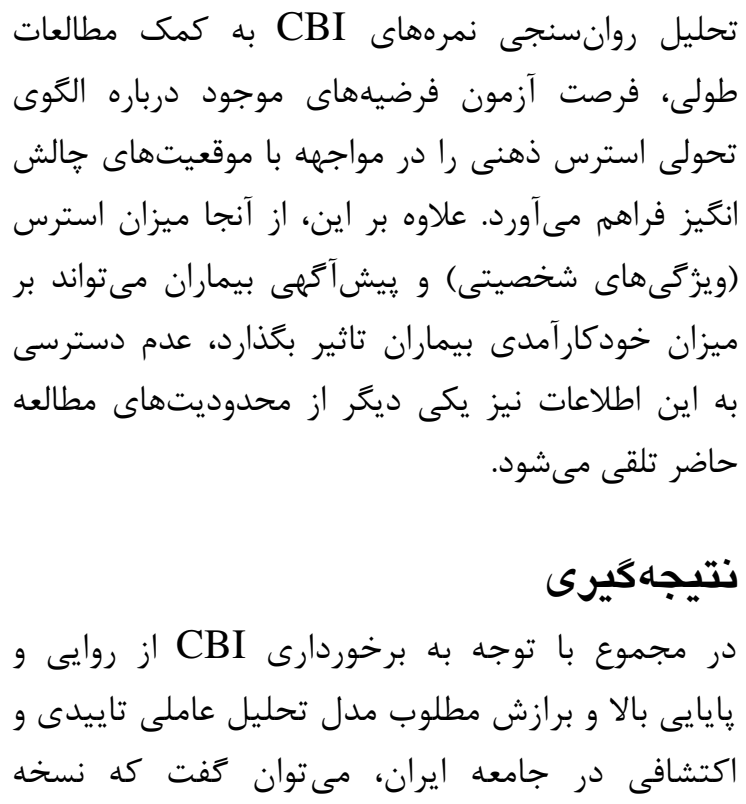

cancer and their informal caregivers: associations with symptoms and distress. Pain. 2008; 137(2):306-15.

7. Mystakidou K, Tsilika E, Parpa E, Panagiotou I, Galanos A, Gouliamos A. Differences in levels of self-efficacy and anxiety between cancer and chronically-ill patients attending a palliative care unit. J BUON. 2012; 17(4):785-90.

8. Foster C, Wright D, Hill H, Hopkinson J, Roffe L. Psychosocial implications of living 5 years or more following a cancer diagnosis: a systematic review of the research evidence. Eur J Cancer Care. 2009; 18:223-47.

9. Kilbreth SH, Refshauge K. Resistance and stretching shoulder exercise early following axillary's surgery for breast cancer. Rehabilitation Oncology. 2006; 24: 9-14.

10. Bandura A. Social foundations of thought and action: A social cognitive theory. 4th Englewood Cliffs: Prentice-Hall, Inc. Mosby; (1986).

11. Baldwin TT, Falciglia GA. Application of cognitive behavioral theories to dietary change in clients. J Am Diet Assoc. 1995; 95(11): 1315-7.

12. Jones F, Riazi A. Self-efficacy and selfmanagement after stroke: a systematic review. Disability and Rehabilitation. 2011; 33(10): 797-810. 
13. So WK, Chow KM, Chan HY, Choi KC, Wan RW, Mak SS, et al. Quality of life and most prevalent unmet needs of Chinese breast cancer survivors at one year after cancer treatment. European Journal of Oncology Nursing. 2014; 18(3): 323-8.

14. Qian H, Yuan C. Factors associated with selfcare self-efficacy among gastric and colorectal cancer patients. Cancer Nurs. 2012; 35(3): 2231.

15. Alipour A, Sahraian MA, Aliakbari M,Hajiaghababae M. The relationship between perceived social support and face hard with mental health and disability status of women sclerosismoltipl. J Social Psychology.2011; 3(1): 110-33.

16. Rottmann N, Dalton SO, Christensen J, Frederiksen K, Johansen C. Self-efficacy, adjustment style and well-being in breast cancer patients: a longitudinal study. Quality of Life Research. 2010; 19(6): 827-36.

17. Telch CF, Telch MJ. Group skills instruction and supportive group therapy for cancer patients: A comparison of strategies. Journal of Consulting and Clinical Psychology. 1986; 54:802-8.

18. Giese-Davis J, Koopman, C, Butler LD, Joss J, Classen C, Roberts J, Spiegel D. The Stanford Emotional Self-Efficacy ScaleCancer: Reliability, validity, and generalizability. In I. Nyklicek, L.Temoshok, \& A. Vingergoets (Eds.), Emotional expression and health:Advances in theory, assessment and clinical applications (pp. 204222).New York, NY: Brunner-Routledge; 2004.

19. Sherer MM, Maddux E. The self- efficacy scale: Construction and validation. Psychology Report. 1982; 51: 663- 671.

20. Michaeli Manee F. Internal consistency and confirmatory factor analysis of Wells and Davis Thought Control Questionnaire. Iran J Psychiatry Clin Psychol. 2011; 16, 468-78.

21. Polit DE, Beck CT. Essentials of Nursing Research: Methods, Appraisal, and Utilization. 6th ed. New York: Lippincott, Williams \&Wilkins; (2013).

22. Iyigun E, Tastan S, Gezginci E, Korkmaz S, Demiral S, Beyzadeoglu M. Cross-Cultural Adaptation and Psychometric Evaluation of the Turkish Version of the Cancer Behavior Inventory-Brief Version. J Pain Symptom Manage. 2017; 54(6): 929-35.

23. Özlem Bozo, İrem Akınc1, Cansu Akyüz. The Psychometric Properties of Cancer Behavior Inventory as a Predictor of Quality of Life in Turkish Cancer Patients. Current Psychology. 2017; 36(135): 1-10.

24. Craig A. White. Cognitive Behaviour Therapy for Chronic Medical Problems: A Guide to Assessment and Treatment in Practice. John Wiley \& Sons Ltd; 2001. 